\title{
Resenha
}

\section{Interview with Prof. Roger A. Sheldon at the "International IUPAC Conference on Green Chemistry", held in 24-29 August 2012, in Foz do Iguaçu, Brazil}

por Vitor F. Ferreira

Prof. Sheldon was born in Stapleford, near Nottingham on June 24, 1942. ${ }^{1}$ He is currently Emeritus Professor of Biocatalysis and Organic Chemistry at Delft University of Technology in the Netherlands. He is also CEO of the spin-off company CLEA Technologies, which he founded in 2002. Prof. Sheldon's research focuses mainly on catalytic oxidation, biocatalysis and green chemistry. He introduced the E-factor concept ${ }^{2}$ that has played an important role worldwide in the development of the pharmaceutical and chemical industries, which are becoming increasingly aware of the problems of waste generation in chemicals manufacture. Since then, as a green knight, he has been publicizing around the world the importance of Green Chemistry.

He presented a plenary lecture at the 4th ICGC (International IUPAC Conference on Green Chemistry) held at the end of
August, 2012 in Foz do Iguaçu - Brazil. He kindly gave Revista Virtual de Química an interview.

RVq: Do you believe that biomass can substitute oil for the generation of fine chemicals?

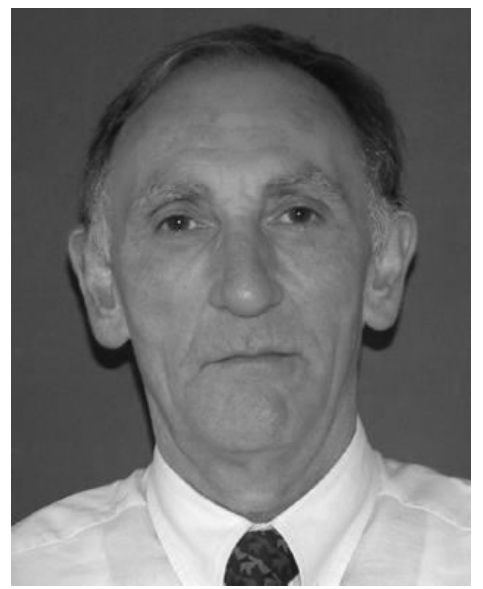

RAS: Yes but, more importantly, I believe that biomass will substitute oil for the production of bulk chemicals in the near future.

RVq: Organic synthesis has advanced tremendously in its methodologies. Are the most important organic chemists thinking their multi-step syntheses with the green philosophy?

RAS: Some are but not all. We need to get all of the
Data de publicação na Web: 24 de Setembro de 2012 Recebido em 23 de Setembro de 2012 Aceito para publicação 24 de Setembro de 2012

most important organic chemists (and also the less important ones) thinking in this way.

RVq: As you said in your conference, some undergraduate books still teach "old version of several reactions". How could we change this situation?

RAS: By paying more attention to Green Chemistry in education. It is important to get the principles and examples of GC into undergraduate textbooks.

RVq: Could you please give us some of your insights about the future of organic chemistry?

RAS: As I noted above, I believe that advances in the various sub-disciplines of catalysis - homogeneous, heterogeneous,

organocatalysis and enzyme catalysis - will play an important role in bringing organic synthesis up to a new level of sophistication and sustainability. In particular, advances in synthetic biology will enable new advances in organic synthesis. 
Interdisciplinary

approaches,

development

e.g.

the

laboratory and an industrial

scale will afford greener,

chemoenzymatic processes

will also be important. The

widespread use of flow

chemistry in organic

synthesis, on both a

\section{Referências bibliográficas}

1 A profile of Roger A. Sheldon, Green Chem., 2004, 6, G55. [CrossRef]

2 Sheldon, R. A. Chem. Ind. (London), 1992, 903.

* Universidade Federal Fluminense, Instituto de Química, Departamento de Química Orgânica, Campus do Valonguinho, 24020-150, Niterói-RJ, Brazil.

Mcegvito@vm.uff.br

DOI: $\underline{10.5935 / 1984-6835.20120062}$ 